OLIVERA ILIĆ

904:634.8”652”(497.11)

Archaeological Institute

711.52:902(497.11:4)”2013”

Belgrade, Serbia

COBISS.SR-ID 212294412

o.ilic@ai.ac.rs

Original research article

MILICA TAPAVIČKI-ILIĆ

Archaeological Institute

Belgrade, Serbia

mtapavic@sbb.rs

ĐORĐE ĆIRIĆ

Stara Pazova

\title{
THE OPENARCH PROJECT: ARCHAEOLOGICAL EXPERIMENT OF PLANTING GRAPEVINE IN VIMINACIUM*
}

\begin{abstract}
This article presents an experiment of planting grapevine according to Roman practice. The experiment was performed in Viminacium and marked the beginning of experimental archaeology at the site of Viminacium. Basis of the experimental vineyard consists of reccomendations given by Roman authors who wrote about different breeding, production and traffic of grapevine and wine. During the experiment the replicas of agricultural Roman tools were used, and made it easier to understand the ways an ancient grapevine breeder worked.
\end{abstract}

Keywords: OpenArch, culture project of the European Union, experiment, Roman agriculture, grapevine.

\section{INTRODUCTION*}

On the $19^{\text {th }}$ of March 2013, as part of the OpenArch project, ${ }^{1}$ which is an international

*The article results from the project: IRS - Viminacium, Roman city and military legion camp - research of material and non material culture of inhabitants by using the modern technologies of remote detection, geophysics, GIS, digitalisation and 3D visualisation (no 47018), funded by Ministry of Education, Science and Technological Development of the Republic of Serbia and the OpenArch project of the European Union.

1 The OpenArch is a five-year cultural project of the European Union which brings together eleven partners from eight European countries: Sweden, Finland, the Netherlands, Great Britain, Germany, Spain and Italy, as well as Serbia, project Viminacium of the Archaeological Institute. This project aims to establish a permanent partnership between the participants - archaeological open-air museums. The project includes performing archaeological experiments, staff exchange and intensive dialogue with visitors. At the same time, within the project, dialogue among archaeologists is established in order to reach standards for performing archaeological experiments, but also with other experts, whose help is often needed for such culture project of the European Union, an experiment of planting grapevine according to Roman practice was performed in Viminacium (Fig. 1). This event marked the beginning of experimental archaeology at the site of Viminacium, aiming to throw light at everyday life in the Roman Empire. The target groups of these actions are scientists, but also a broader public interested in this matter, reached through the methods of museum pedagogy. In order to achieve this, the purpose of the experimental vineyard in the Archaeological park of Viminacium is growing grapevine in the way it has been done some two millenia ago.

Grapevine, actually its products like grapes and wine, represent one of the important factors of Roman economy, culture, tradition and everyday life. It is therefore no wonder that numerous ancient authors wrote about this plant and its fruit in differ-

experiments. Finally, it is planned to publish several publications and multimedia presentations related to the project contents. 


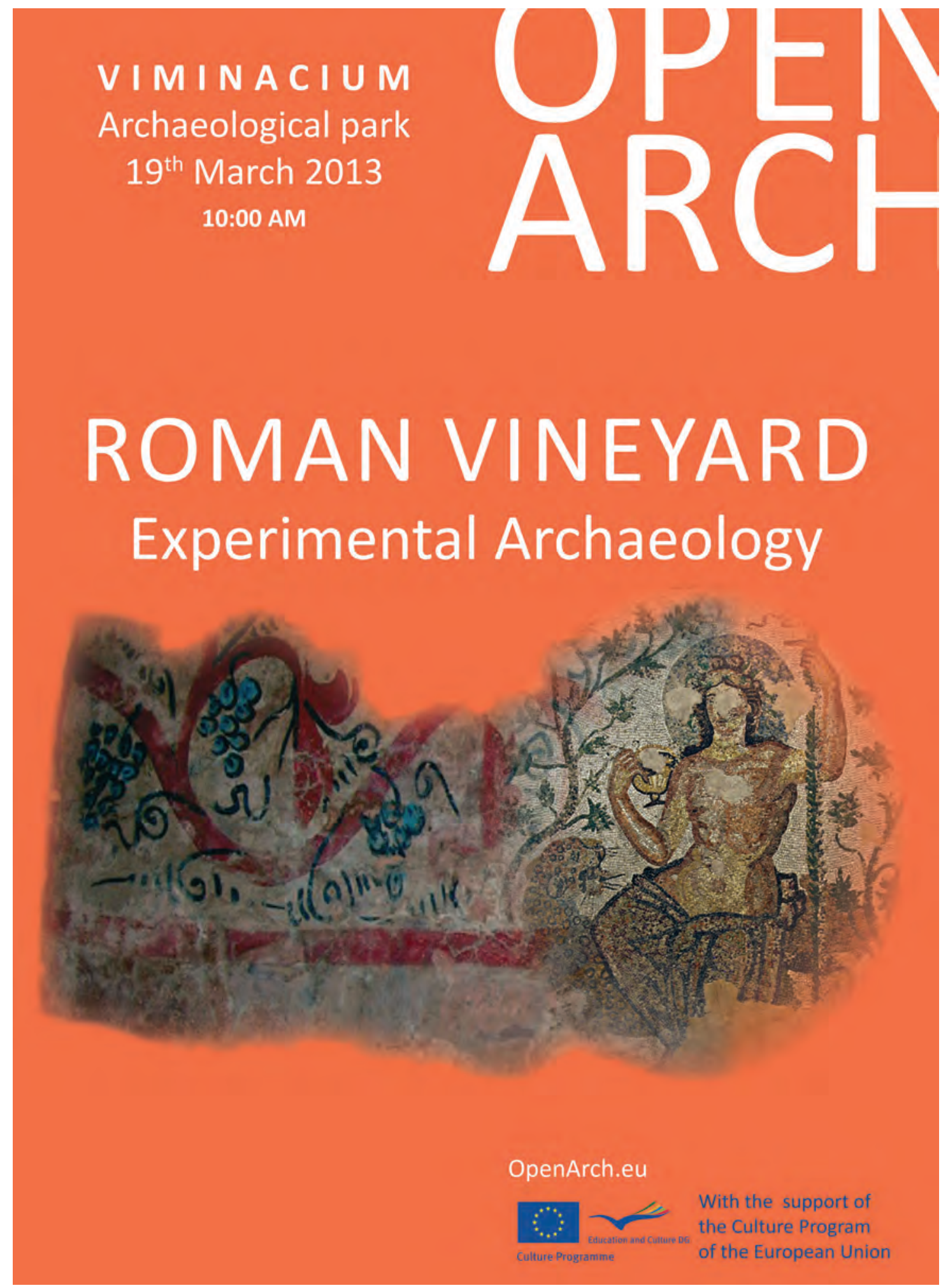

Fig. 1 Poster - Roman vineyard

ent ways. Data about grapevine and wine are left be mentioned: Cato ${ }^{2}$, Varro ${ }^{3}$ and Columella ${ }^{4}$. Exby Roman authors who wrote about aspects of its 2 Cato, De Agricultura, written around 160 BC. breeding, production and traffic. Here, several shall 3 Varro, De Re Rustica, written around $30 \mathrm{BC}$.

4 Columella, De Re Rustica, written around 60-65 AD. 
actly recommendations from their writings represent basic rules which were followed while performing the experiment at Viminacium. More precisely, two sources were taken as the most appropriate to be applied in the Viminacium vineyard.

First of all there is Columella ${ }^{5}$, who wrote a voluminous work entitled De Re Rustica in twelve books. The work was written in the $1^{\text {st }}$ century $\mathrm{AD}$, representing the most detailed description of ancient grapevine breeding. It is also of great importance that he quoted other authors, so there is a broader practice and knowledge on this matter.

Another source is Geoponica ${ }^{6}$, which is not from the period of the Roman Empire. The original Greek text of the author Cassianus Bassus, from the end of the $6^{\text {th }}$ and the beginning of the $7^{\text {th }}$ century is not completely preserved, but some of their parts were compiled by Constantine VII Porphyrogennetos in the middle of the $10^{\text {th }}$ century. The work represents as a compilation of agriculture practices and recommendations. Most of the texts within this voluminous work (twenty volumes) are rooted in Roman agricultural practice.

\section{TOOLS USED DURING THE EXPERIMENT}

The breeding of grapevine according to recommendations of ancient authors leads one into a broader spectrum of mechanisms and customs which were available to people of that time. First of all, the dynamics of actions was based on a different system (lunar cycle), while the working area was rather specific (wine). Due to the quickest way possible of introducing Roman grapevine breeding, replicas of agricultural tools were made

5 Columella, De Re Rustica in twelve volumes has been completely preserved and forms an important source on Roman agriculture. Grapevine is described in the third and the fourth book, while vinary is described in the twelvth book.

6 Cassianus Bassus lived at the end of the $6^{\text {th }}$ or the beginning of the $7^{\text {th }}$ century. He compiled from earlier writers a collection of agricultural literature. Dedicated to his son, his work was entitled Eklogaiperigeorgias. The usual Latin version of this title is Eclogae de Re Rustica. The original Greek text of Cassianus Bassus has been lost, but some of the contents have survived as part of a collection entitled Geoponica (in twenty volumes) completed about the year 950 and dedicated to the emperor Constantine VII Porphyrogennetos. used during the Roman period and adjusted to the soil structure in the Serbian Danube valley. By using such tools, which is still in a way different compared to modern tools, made it easier to understand the ways an ancient grapevine breeder worked during Roman times.

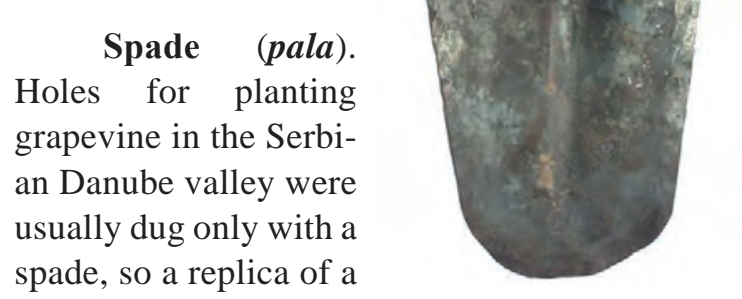
Roman spade was used during the experiment (Fig. 2). Spades were

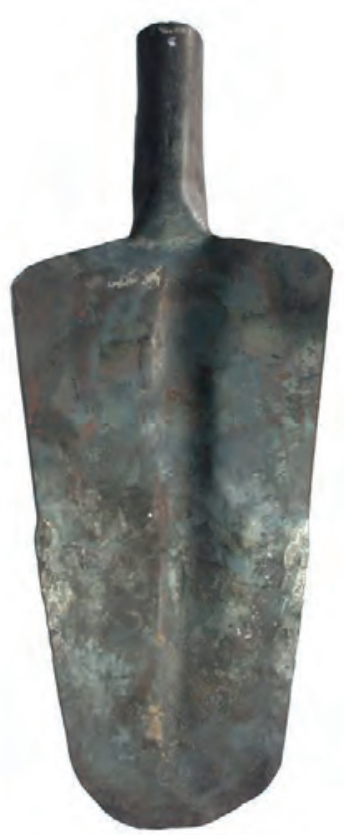

Fig. 2 Replica of Roman spade broadly in use in Roman agricultural production. Apart from their usage in gardening, vegetable breeding and drainage, it was also used in vineyards. Written sources describe several tools which, according to their shape and function, colud be called spades: pala, bipalium and scudicia. The replica of the Viminacium spade was made according to a mediaeval type which was widely used throughout the Balkans. Soil quality and structure surely caused different blade shapes, so the Mediterranean types and quite different from those used in the inland.

Spade finds from the Roman provinces at the territory of modern Serbia are not so numerous, indicating that apart from the iron spades, wooden spades were also used. Most of them are known from the Brović hoard near Obrenovac (Бојовић 1978: 185-195) and Šljivovac near Kragujevac (Петровић 1966: 253-256). Still, one can presume that such a tool was frequently used on this soil and that a small number of finds is caused by insuficcient number of performed research. Chronologically, all of the finds discovered belong to the period of Late Antiquity, i.e. $3^{\text {rd }}$ and $4^{\text {th }}$ century (Поповић 1988: 33-34).

Bident hoe (bidens). The second tool used during the experiment was a bident hoe (Fig. 3). 


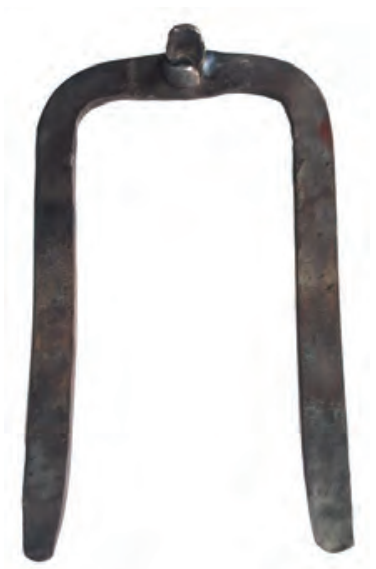

Fig. 3 Replica of Roman bident hoe
In written sources, it is mentioned as bidens, which is an abbrevation of bidensrastrum, in order to make a difference from rake (rastrum) which had more dents (White, 1967: 47-49).

Bident hoe is one of the most popular tools used in agriculture. Bidens which weights less, the socalled light bidens, was an obligatory tool used in vineyards. It was used for spreading soil around the vine roots, at the same time making sure that roots do not get cut.

Finds of bident hoes are not so rare at the territory of Serbia, so this kind of tool was divided into several basic types and variants (Поповић 1988: 44-46). They are of simple construction, usually hammered from a single piece of iron, with two flat, more-or-less parallel dents. The dent ends are flat, horizontally connected at the upper ending. In the middle of the horizontal part there was a handle hole. This type was found at the broader territory of the Danubian Limes (Grocka, Požarevac area, Boljetin, Majdanpek) and it is usually dated into the $4^{\text {th }}$ century.

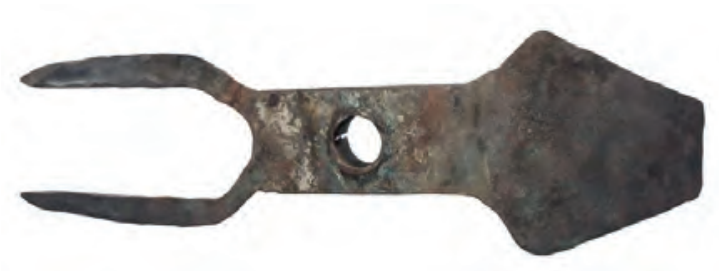

Fig. 4 Replica of Roman garden hoe

Garden hoe (ascia-rastrum). Written sources describe the garden hoe as a kind of agricutural tool representing a combination of a bident hoe and a pickax (Isidore, Etymologiae, 19. 19. 12), (Fig. 4).

Garden hoes were used for all of the works for which a bident hoe or different kinds of pickaxes were used, actually for surface cultivation of gardens and preparing the soil for planting grapevine (White, 1967: 67-68).

Finds of this tool are not rare at the territory of Serbia and they all belong to the same type, with a flat blade in the shape of a pickaxe on one side and a bident hoe on the other side. There is a handle hole in the middle. There are several variants of this type coming from the Serbian Danube and the Morava valleys: Sremska Mitrovica, the „Zelengora“ field hoard, Saldum, Salakovac near Požarevac (Поповић 1988: 47-48). Chronologcally, they all belong to the Late Antique period, i.e. the $3^{\text {rd }}$ and $4^{\text {th }}$ century.

\section{DESCRIPTION AND RESULTS OF EXPERIMENTAL GRAPEVINE PLANTING}

During the experiment, it was decided to plant twenty vines and to follow their development from planting to picking, all of that by following Roman practices of agrotechnical measures applied in ancient times (Fig. 5). Since the number of vines was small, it was necessary to show Roman practices as authentic as possible. This is why trees were used as supports for grapevines, actually all of the vines were planted next to oak trees. The way of planting vines next to trees in not necessarily a Roman practice, but it is known that Romans highly appreciated this kind of planting. The best wines of Roman times (Phalerian and Surrentine) came from vineyard which were planted in such a manner.

The practice of growing vines next to trees exists today also, but rarely and only in those climates and economic conditions which allow that. It is encountered all over Italy, in the areas of Tuscany, Veneto and Romagna, under the name of malberate. During the eight decade of the $19^{\text {th }}$ century, one of the latest descriptions of growing vine next to trees in Serbian vineyard areas was left by Konstantin Jiriček. He describes thick vines growing around trees on the slopes of Oplenac (К. Јиречек 1959: 71-190).

As best tree sorts, Roman authors recommend planting vines next to poplar, maple, ash and oak (Siberian oak - Ulmus pumila), the latest one used as support in the Viminacium vineyard during the experiment. These tree sorts either possess weakly developed, not very huge roots, which do not disturb the 


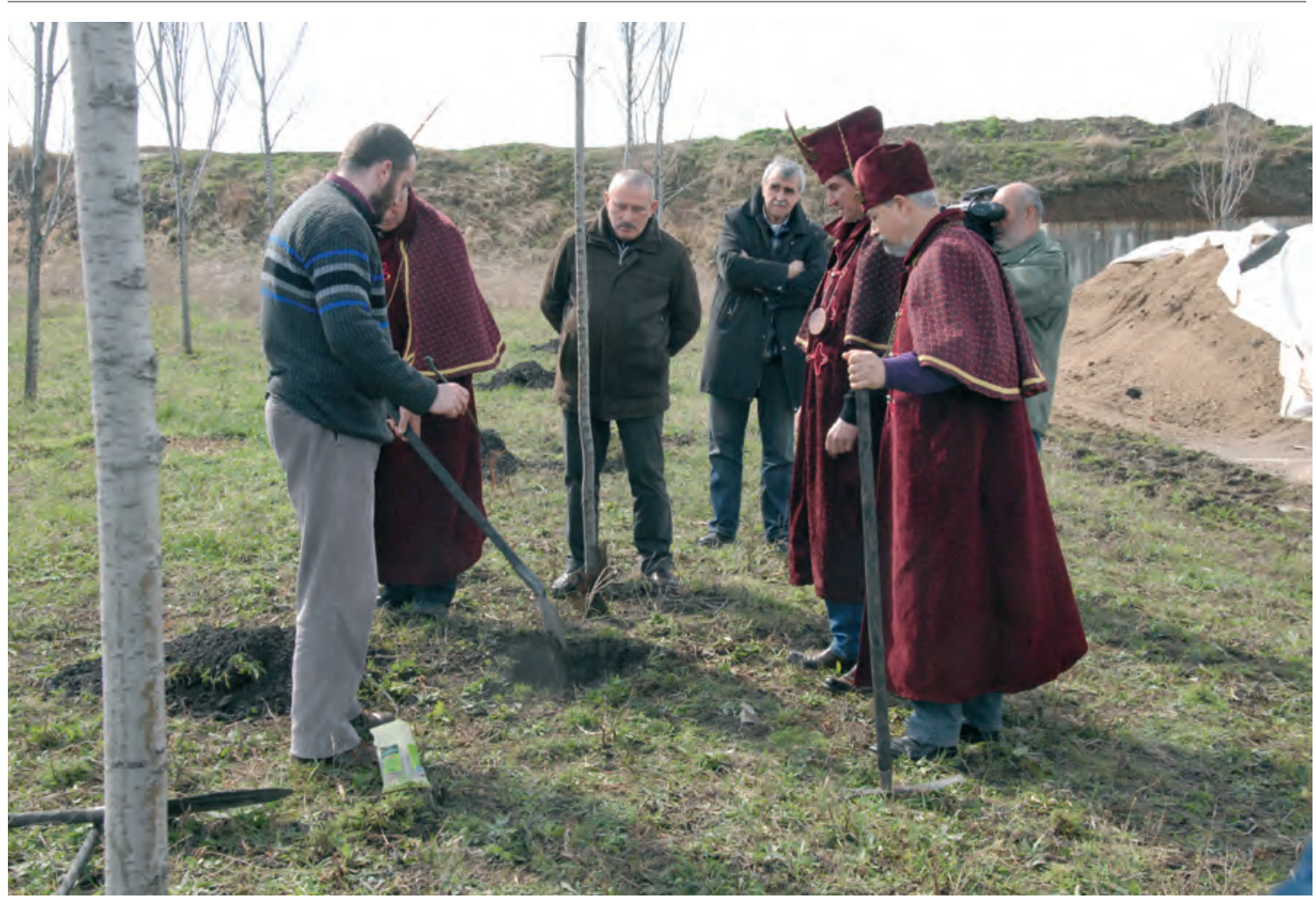

Fig. 5 Archaeological experiment - grapevine planting

vine roots, or their leaves are not too thick to shade vine leaves. Tree height should not exceed forty Roman feet, while the first branches which would be used as support for vine should go in the east-west direction. In such a way, the vine branches spread wreath-like over the cut branches of a host-tree.

During planning the future vineyard and since the experiment mostly relies on enological science, directions were followed given within enology. The first thing determining the future vineyard was the sort of vine to be planted, actually a sort typical for the area. The sources reveal that the best Roman sorts were white wines, sweet and with the aging capacity. This is why Phalerian wine was regarded as suitable for drinking after ten years and the Surretine wine even after twenty-five years of aging in closed vessels.

In Roman vineyards, numerous sorts were grown in different climatic conditions and different soils. Still, not all sorts are suitable for being grown just in any areas. This was also known to the ancient authors, so they gave directions about which sorts are more or less suitable for certain areas. The climate of the wider Viminacium area is certainly different from the Mediterranean cli- mate. This is why the choice was made which was appropriate to the mild continental climate and the soil of the Stig. It is quite possible that after the occupation, the Romans came upon certain vine sorts at the territory of what is now modern Serbia, but it is also possible that during the four hundred years of their domination, they made a selection. ${ }^{7}$ During the reconstruction of the vine sort, there was an important fact at disposal about re-establishment of vineyards all over Europe undertaken by Marc Aurel Probus (Marcus Aurelius Probus). He abolished the prohibition by the emperor Domitianus, which prohibited planting vineyards outside the Apennine peninsula and the first areas to be re-planted were the slopes of southern Fruška Gora (Alma Mons), the hills above the Danube along the Via Militaris and Zlatno brdo

7 Data not strictly confirmed report that vines planted on these two locations were brought from Asia Minor. The names of sorts grown at that time are known and there are even descriptions of some of them, but it cannot be claimed whether they remained unchanged until present times. Even if a DNA analysis would determine the origin, it would not mean too much, since there are numerous mutations of vine, caused mostly by growing conditions. Growing conditions are those determining development of vines even more than its original potentials. 

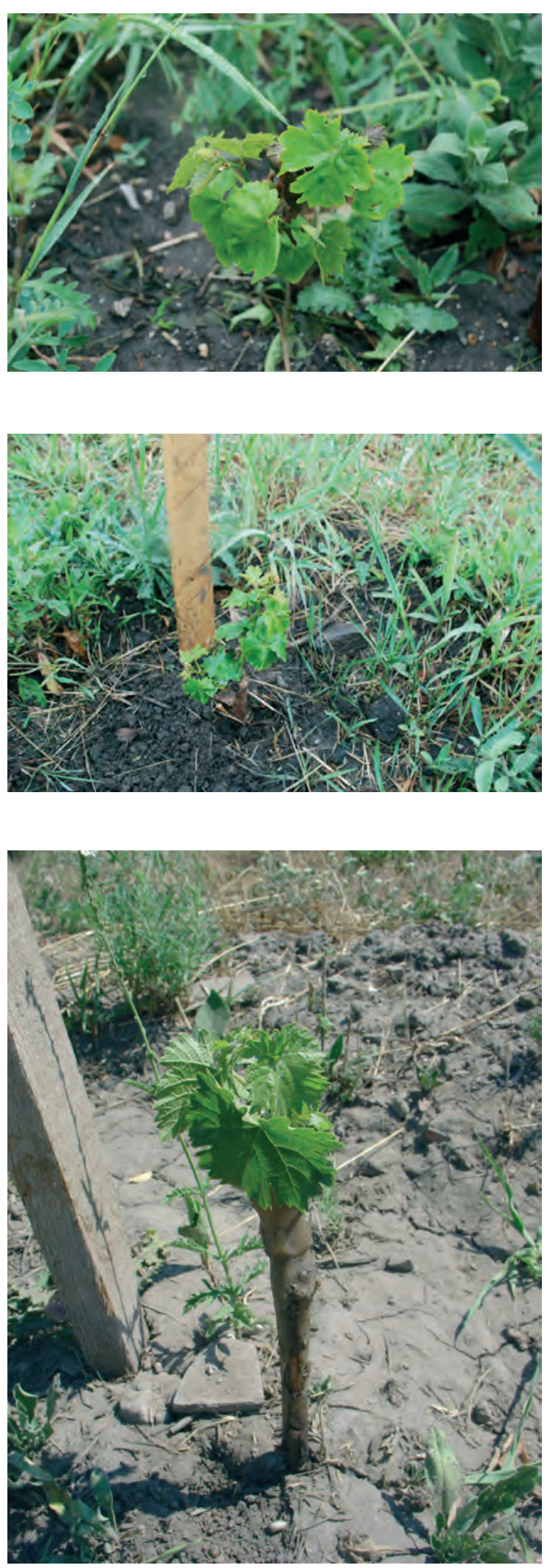

Fig. 6 a-c The appearance of the vine in May 2013, (ab); in August 2013 (c)
(Aureus Mons) near Smederevo (Mirković1968: 139; Mócsy, 1974: 298-299).

White tamianika is a sort which in many ways correspond to sorts known from ancient Roman sources. It gives white wines which only get better when left to age. It is not known with certainty when this sort was imported into this area. In the middle of the $14^{\text {th }}$ century, it is mentioned in written sources describing the vicinity of Dubrovnik and Kotor. ${ }^{8}$ Ancient sources are also determined about not planting different vine sorts in one single vineyard, so this practice was also followed while planting the Viminacium vineyard. The single sort planted was the white tamianika.

After choosing the sort, the planting spots were chosen. Ancient authors left numerous data about this matter, so some of them were applied. As written in the Geoponica (V, 4), planting must always be adjusted to the features of the chosen location. If a vineyard is planted in a warm area, vines must be orientated towards the north and vice versa, if it is planted in a colder area, the vines must face the south. If the climate is mild, it is the best to orientate the vine rows towards the east. Mild winds suit vines, but it can also easily be damaged by stormy winds. The opinion of most of the vine breeders is that vineyards should not be planted near rivers, let along swamps, since moisture and cold air permanently raise from these areas, bringing bad air. In the mentioned work $D e$ re rustica, Columella (III, 1.10.) confirms that neither cold climate nor hot summers suit vine, although it grows better in warmer climatic conditions. Rainy weather brings more damage than hot weather and it is better to plant vines in a hot area than in a rainy one.

According to Celsus (De re rustica, III, 1.8.), soil shoud not be too hard, neither too loosely, but closer to loosely, neither too rich nor too poor, but closer to fertile, neither too flat not too steep, but hilly, neither damp nor dry, but mildly damp. Similar data are known from Geoponica (volume V, 7), in which there are methods described of checking whether soil is fertile enough for planting vine resembling modern pedologic methods. During the experiment, holes were dug

8 Within Negrulj's classification from 1946 and according to its geographic origin, white tamianika is regarded as a sort originating from the Middle East, which in a certain way can help reconstruct the sorts planted at the Aureus Monsu during the eigth decade of the $2^{\text {nd }}$ century. 
two Roman feet deep, intended for planting, but the fertility checking was performed only in one hole. Some of the excavated soil was taken and put into a glass vessel. After that, soil and water were mixed until a perfect sediment is formed, well visible through the glass. This mixture needs to be tasted, certainly only a fingertip of it, and according to the taste it leaves on one's senses, future wine can be estimated, since the taste of water is expected to correspond to the taste of wine. If the taste is unsatisfactory, such a soil shall not give good wine. On the other hand, if the taste is nice and sweet, future wine can be expected to be of good quality.

All of the instruction mentioned above are applied for more than two millennia and, with some modifications, they are known to every winegrower, no matter where he/she grows his/her vineyard. According to ancient authors, the Viminacium vineyard is not placed in an area ideal for growth. This is why the Viminacium vines were planted next to Siberian oak trees, since according to Geoponica, in such a way they would be more resistable to inconvenient climatic conditions.

Ancient authors also recommend the best times for planting. From the very beginning of its cultivation in the European areas with mild continental climate, vine is planted during the time of its biologic quiescence. This corresponds to the seasons of spring and autumn. Roman practice also determins even more precisely the time of planting by bringing it in connection with the movement of the Moon and the Sun. Columella (III, 14.) recommends that planting in dry and warm areas is better in autumn. Rainy and cold areas, also including the Viminacium area, are better to be planted in spring. During spring, there are about forty days suitable for planting and these are from the Idae of February to the spring equinox. In Geoponica, there is one more information $(\mathrm{V}, 6,10)$. By following the cycle of the Moon, it is recommended to plant during the increasing Moon. In any case, all of the ancient sources agree that it is not suitable to plant vine after the spring equinox. The Viminacium vine was therefore planted in spring (on the $19^{\text {th }}$ of March), slightly before the spring equinox. This was another way of following ancient sources on the matter.

The last action undertaken in this experiment was planting itself. In ancient vineyards, measuring was performed, since vines were planted at distances of five Roman feet. Measuring was not performed in the Viminacium vineyard, since the vines were planted next to oak trees. On the other hand, the data about depth of holes differ from author to author. It is recommended that they should not be less than two and a half feet deep on flat grounds, resembling the Viminacium one. According to the opinion of the authors of the experiment, the hole depth described by Columella was suitable and it was therefore applied.

For the soil type of Viminacium (heavier mechanic structure), planting of vines with the already formed roots was recommended. The Romans often planted two vines in a single hole, so this is what was also done in Viminacium. On such occasions, their roots were separated with pebbles and they were placed one opposite to the other, slightly diagonally into the hole. Either during planting one or two vines into a single hole, the measure which even in modern times is often applied is to mix manure with soil and to fill holes with such a mixture.

Apart from regular measures undertaken while plantin Roman vineyards, some other, rather exotic measures were sometimes performed, in order to ensure the planted vines to be fruitful and grow tasty grapes. For grapes of good quality, grape seeds were sometimes put into the holes - if a planted sort was white, seeds of red vines were put and vice versa.

In order to root the vines better and be fruitful, a mixture of crushed oak bark and lens was put into the holes. Dried lens or broad bean seeds were also put into the holes to reject rodents, which was also applied in the Viminacium vineyard. This specifically was the last action performed during the experiment on the $19^{\text {th }}$ of March 2013.

\section{CONCLUSION}

After following the growth on vines in the Viminacium vineyard it was ascertained that in May 2013, all twenty of vines were still alive. In August 2013, two of them withered during the very dry summer, still leaving eighteen healthy vines (Fig. 6 a-c).

The next step of Viminacium experiment is an attempt to cultivate some of the species grown at the Apennine peninsula. In this way, one should be able to understand whether in Roman times, it was pos- 
sible to transfer plant species, actually whether the species grown in Italy were also capable of growing elsewhere, thus making it possible to produce excellent wines also in our region. Further steps of this experiment might give answers to this question.

\section{BIBLIOGRAPHY}

\section{Бојовић, Д. 1978}

Остава римског пољопривредног алата из села Бровић код Обреновца, ГГБ XXV, Београд: Музеј града Београда: 185-195.

Јиречек, К. 1959

Војна иеста од Београда за Цариград и балкански кланщи, Зборник К. Јиречека I, Београд: Српска академија наука и уметности / САНУ - Одељење друштвених наука: 71-190.

\section{Mirković, M. 1968}

Rimski gradovi na Dunavu u Gornjoj Meziji, Dissertationes, Beograd: Arheološko društvo Jugoslavije.

\section{Mócsy, A. 1974}

Pannonia and Upper Moesia: a history of the middle Danube provinces of the Roman Empire, London and Boston: Routledge \& Kegan Paul.

Петровић, Д. 1966

Остаци римске грађевине у Поскурицама, Старинар XV-XVI, Београд: Археолошки институт: 253-256.

\section{Поповић, И. 1988}

Античко оруће од гвожђа у Србији, Београд: Народни музеј: 1988.

White, K. D. 1967

Agricultural Implements of the Roman World, Cambridge: University Press.

\section{REZIME}

\section{OPENARCH PROJECT: ARHEOLOŠKI EKSPERIMENT SAĐENJA VINOVE LOZE U VIMINACIJUMU}

Ključne reči: OpenArch, projekat kulture Evropske Unije, eksperiment, rimska poljoprivreda, vinova loza.

U okviru međunarodnog projekata kulture Evropske Unije, OpenArch, 19. marta 2013. godine u Viminacijumu je izveden eksperiment sađenja vinove loze prema rimskoj praksi. Za osnovu oglednog vinograda u Viminacijumu uzete su preporuke rimskih autora koji su se bavili različitim aspektima uzgoja, proizvodnje i prometa vinove loze i vina. To je pre svega Kolumela, sa svojim monumentalnim delom De re rustica. Drugi spis pod nazivom Geoponika nastao je sredinom X veka i predstavlja kompilaciju saveta o poljoprivredi. Većina tekstova u ovom obimnom spisu vuče korene iz rimske prakse.

Radi što bržeg uvođenja u svet rimskog vinogradarstva izrađene su replike poljoprivrednih alatki: ašova, dvozube motike i baštenske motike. Prilikom eksperimenta sađenja vinove loze, određeno je da se da prati dvadesetak čokota od njihovog sađenja, pa sve do prve berbe, primenjujući rimsku praksu za sve agro-tehničke mere vinogradarstva tog perioda. 